\section{Epilepsy Genetics: Yet More Exciting News}

One of the great successes in epilepsy research over the past 10 years has been the identification of single gene mutations that are the basis of rare, familial epilepsy syndromes with autosomal dominant patterns of inheritance (Table). To date, most of the mutations associated with relatively "pure" epilepsy phenotypes (ie, idiopathic generalized epilepsies in which there are few, if any, other abnormalities of brain function) have turned out to be in genes encoding ion channels and receptors. Two notable examples are the syndrome of "generalized epilepsy with febrile seizures plus" (GEFS+), which has been linked to mutations in genes encoding sodium channel and GABA receptor subunits, and the syndrome of "benign familial neonatal convulsions," which has been linked to mutations in genes encoding potassium channel subunits.

The most recent ion channel to be added to the list of epilepsy channelopathies is the T-type calcium channel. T channels are activated by small depolarizations near the resting membrane potential. Three types exist in mammals: $\mathrm{Ca}_{\mathrm{v}} 3.1, \mathrm{Ca}_{\mathrm{v}} 3.2$, and $\mathrm{Ca}_{\mathrm{v}} 3.3$. A role for T-type calcium channels in the pathophysiology of generalized epilepsy, especially absence epilepsy, has been known for some time; these channels are critically involved in normal burst-mode firing of the same thalamocortical circuitry recruited in the characteristic spike-wave discharges observed in absence seizures. This role is supported by two different genetic models of generalized epilepsy: the genetic absence epilepsy rat from Strasbourg (GAERS), in which expression of $\mathrm{Ca}_{\mathrm{v}} 3.1$ and $\mathrm{Ca}_{\mathrm{v}} 3.2$ are increased; and $\mathrm{Ca}_{\mathrm{v}} 3.1$ knock-out mice, which show resistance to certain forms of experimental epilepsy. Furthermore, the antiepileptic drugs most effective against absence epilepsy and generalized epilepsies, ethosuximide and valproic acid, inhibit T-type channel function.

The first evidence of an association between genetic variation in T-type calcium channels gene and epilepsy came in 2003, when Chen and colleagues ${ }^{1}$ performed direct sequencing of exons 3 to 35 and the exon-intron boundaries of the human gene for $\mathrm{Ca}_{\mathrm{v}} 3.2$, CACNA1H, in 118 Han Chinese patients with childhood absence epilepsy. They found 12 different missense mutations in 14 of 118 patients but none in 230 unrelated control subjects. Subsequent studies identified additional missense mutations in this gene in patients with childhood absence epilepsy ${ }^{2}$ and in idiopathic generalized epilepsy. ${ }^{3}$ In general, these mutations occurred in highly conserved residues, and functional studies indicated that several variants alter channel function in a manner predicted to increase network excitability. ${ }^{4-6}$ Importantly, the approach used for identifying mutations - that is, direct sequencing of candidate genes for rare functional variants in cohorts of patients whose epilepsy is a consequence of more complex genetic effects-has borne fruit in other instances as well. For example, polymorphisms and functional mutations in various GABA receptor subunits and the potassium channel subunit KCND2 have been identified in epilepsy patients and in unaffected individuals as well, suggesting that these variations may contribute to an overall increase in susceptibility for epilepsy rather than having a large dominant effect.

In this issue of Annals of Neurology, Heron and colleagues $^{7}$ describe the results of screening for CACNA1H variants in a large cohort of 240 epilepsy patients and 95 control subjects of mainly white origin. They identified 19 new variants in subjects with childhood absence epilepsy, juvenile absence epilepsy, juvenile myoclonic epilepsy, myoclonic-astatic epilepsy febrile seizures, and temporal lobe epilepsy. All variants were also found in unaffected individuals, though in some families, variants segregated with epilepsy. Among 11 variants examined by electrophysiology, most showed altered channel kinetics that could predispose to network dysfunction. These results extend the list of epilepsy syndromes associated with CACNA1H variants and identify novel variants in Caucasian patients that were not found in Han Chinese. The number of epilepsy syndromes associated with functional CACNA1H polymorphisms and the variable incidence of their segregation with epilepsy within families suggest that CACNA1H variants can contribute to epilepsy risk but alone do not cause epilepsy. As the authors imply, dissecting apart the population genetics of what is likely to be many susceptibility genes will be a challenging and complex task, but one that is sure to lead to more effective approaches for the diagnosis and treatment of many common seizure disorders.

Daniel Lowenstein, MD and Robert Messing, MD

Department of Neurology

University of California, San Francisco

San Francisco, CA

\section{References}

1. Chen Y, Lu J, Pan H, et al. Association between genetic variation of CACNA1H and childhood absence epilepsy. Ann Neurol 2003;54:239-243.

2. Liang J, Zhang Y, Wang J, et al. New variants in the CACNA1H gene identified in childhood absence epilepsy. Neurosci Lett 2006;406:27-32. 
Table. Examples of Functional Effects of Ion Channel Mutations Associated with Epilepsy

\begin{tabular}{|c|c|c|c|c|}
\hline Human Epilepsy & Affected Gene & $\begin{array}{l}\text { Affected } \\
\text { Current }\end{array}$ & $\begin{array}{l}\text { Effect on the } \\
\text { Current }\end{array}$ & Main Functional Mechanism \\
\hline BFNC & $K C N Q 2, K C N Q 3$ & M-current & Loss of function & $\begin{array}{l}\text { Decreased expression or modifications of gating kinetics } \\
\text { that reduce } \mathrm{K}^{+} \mathrm{M} \text {-current induced hyperpolarization }\end{array}$ \\
\hline $\begin{array}{l}\text { Focal familial seizures } \\
\text { and myokymia }\end{array}$ & $K C N A 1$ & $\begin{array}{l}\text { Delayed } \\
\text { rectifier }\end{array}$ & Loss of function & $\begin{array}{l}\text { Decreased delayed rectifier } \mathrm{K}^{+} \text {current by various mecha- } \\
\text { nisms }\end{array}$ \\
\hline $\begin{array}{l}\text { Generalized epilepsy } \\
\text { and paroxysmal } \\
\text { dyskinesia }\end{array}$ & KCNMA1 & $\mathrm{IK}_{\mathrm{Ca}}(\mathrm{BK})$ & Gain of function & $\begin{array}{l}\text { Enhanced } \mathrm{Ca}^{2+} \text { sensitivity (cell hyperexcitability may be } \\
\text { caused by rapid action potential repolarization and } \\
\text { enhanced recurrent firing) }\end{array}$ \\
\hline BFNIC & $S C N 2 A$ & $\mathrm{INa}$ & Gain of function & $\begin{array}{l}\text { Increase of current by various modifications of voltage } \\
\text { dependence of gating }\end{array}$ \\
\hline GEFS + type 1 & $S C N 1 B$ & $\mathrm{INa}$ & Gain of function & $\begin{array}{l}\text { Variable according to the expression system, often loss of } \\
\text { modulation of } \mathrm{I}_{\mathrm{NaT}} \text { inactivation }\end{array}$ \\
\hline \multirow[t]{7}{*}{ GEFS + type 2} & $S C N 1 A$ & $\mathrm{INa}$ & $\begin{array}{l}\text { Gain or loss of } \\
\text { function }\end{array}$ & $\begin{array}{l}\text { Variable according to the mutation, expression system, } \\
\text { and complementary DNA used }\end{array}$ \\
\hline & & & & $\begin{array}{l}\text { Slowed time course of } \mathrm{I}_{\mathrm{NaT}} \text { inactivation and faster recov- } \\
\text { ery from inactivation }\end{array}$ \\
\hline & & & & Decreased use-dependent inactivation \\
\hline & & & & $\begin{array}{l}\text { Enhanced } I_{\mathrm{NaP}} \text { fraction and decreased fast inactivation of } \\
\mathrm{I}_{\mathrm{NaT}}\end{array}$ \\
\hline & & & & $\begin{array}{l}\text { Hyperpolarizing shift of both } \mathrm{I}_{\mathrm{NaT}} \text { activation and inactiva- } \\
\text { tion causing a hyperpolarizing shift of window current }\end{array}$ \\
\hline & & & & $\begin{array}{l}\text { Reduced current and enhanced recovery from slow } \mathrm{I}_{\mathrm{NaT}} \\
\text { inactivation }\end{array}$ \\
\hline & & & & $\begin{array}{l}\text { Depolarizing shift of } \mathrm{I}_{\mathrm{NaT}} \text { steady-state inactivation be- } \\
\text { cause of altered interaction with } \beta 1 \text { subunit }\end{array}$ \\
\hline \multirow[t]{2}{*}{ SMEI } & $S C N 1 A$ & $\mathrm{INa}$ & $\begin{array}{l}\text { Gain or loss of } \\
\text { function }\end{array}$ & No current \\
\hline & & & & Enhanced $\mathrm{I}_{\mathrm{NaP}}$ fraction \\
\hline \multirow[t]{2}{*}{ ICEGTC } & $S C N 1 A$ & $\mathrm{INa}$ & $\begin{array}{l}\text { Gain or loss of } \\
\text { function }\end{array}$ & No current \\
\hline & & & & $\begin{array}{l}\text { Various effects on gating properties according to the mu- } \\
\text { tation }\end{array}$ \\
\hline FS & SCN1A & $\mathrm{INa}$ & Loss of function & $\begin{array}{l}\text { Decreased current, positive shift voltage dependence of } \\
\text { activation }\end{array}$ \\
\hline $\begin{array}{l}\text { Absence epilepsy and } \\
\text { episodic ataxia }\end{array}$ & $C A C N A 1 A$ & $\mathrm{ICa}(\mathrm{P} / \mathrm{Q})$ & Loss of function & $\begin{array}{l}\text { Decreased P/Q } \mathrm{Ca}^{2+} \text { current by reduced membrane tar- } \\
\text { geting }\end{array}$ \\
\hline CAE & $C A C N A 1 H$ & $\mathrm{ICa}(\mathrm{T})$ & $\begin{array}{l}\text { Gain or loss of } \\
\text { function }\end{array}$ & $\begin{array}{l}\text { Various effects on gating properties of T-type } \mathrm{Ca}^{2+} \text { chan- } \\
\text { nels }\end{array}$ \\
\hline $\begin{array}{l}\text { IGE and episodic } \\
\text { ataxia }\end{array}$ & CACNB4 & $\mathrm{ICa}$ & Gain of function & $\begin{array}{l}\text { Decrease in the fast inactivation time constant when co- } \\
\text { expressed with } \alpha \text { subunit }\end{array}$ \\
\hline \multirow[t]{2}{*}{$\begin{array}{l}\text { IGE with absences } \\
\text { and convulsions }\end{array}$} & $C L C N 2$ & $\mathrm{ICl}$ & Loss of function & $\begin{array}{l}\text { Complete loss of function causing decreased transmem- } \\
\text { brane } \mathrm{Cl} \text { gradient (and GABA inhibition) }\end{array}$ \\
\hline & & & & $\begin{array}{l}\text { Changes in voltage-dependent gating (membrane depolar- } \\
\text { ization?) }\end{array}$ \\
\hline GEFS + type 3 & $G A B R G 2$ & $\mathrm{I}_{\mathrm{GABA}}$ & Loss of function & $\begin{array}{l}\text { Decreased current amplitude by reduced membrane tar- } \\
\text { geting and receptor assembly }\end{array}$ \\
\hline $\mathrm{CAE}$ and $\mathrm{FS}$ & $G A B R G 2$ & $\mathrm{I}_{\mathrm{GABA}}$ & Loss of function & Loss of benzodiazepine sensitivity \\
\hline JME & $G A B R A 1$ & $\mathrm{I}_{\mathrm{GABA}}$ & Loss of function & Reduced GABA sensitivity and altered channel gating \\
\hline ADNFLE type 1 & CHRNA4 & $\mathrm{nAChR}$ & Loss of function & Various effects \\
\hline \multirow[t]{2}{*}{ ADNFLE type 3} & CHRNB2 & $\mathrm{nAChR}$ & Gain of function & Slower desensitization \\
\hline & & & & Increase in acetylcholine sensitivity \\
\hline \multicolumn{5}{|c|}{$\begin{array}{l}\text { BFNC = benign familial neonatal convulsions; BFNIC = benign familial neonatal-infantile convulsions; INa = sodium current; GEFS }+= \\
\text { generalized epilepsy with febrile seizure plus; INaT = transient sodium current; INaP = persistent sodium current; SMEI = severe myoclonic } \\
\text { epilepsy in infancy; ICEGTC = intractable childhood epilepsy with generalized tonic-clonic seizures (a disorder similar to SMEI); FS = febrile } \\
\text { seizures; CAE = childhood absence epilepsy; IGE = idiopathic generalized epilepsy; JME = juvenile myoclonic epilepsy; ADNFLE = } \\
\text { autosomal dominant nocturnal frontal lobe epilepsy; nAChR = nicotinic acetylcholine receptor. } \\
\text { Adapted with permission from Avanzini G, Franceschetti S, Mantegazza M. Epileptogenic channelopathies: experimental models of } \\
\text { human pathologies. Epilepsia 2007;48:51-64. }\end{array}$} \\
\hline
\end{tabular}


3. Heron SE, Phillips HA, Mulley JC, et al. Genetic variation of CACNA1H in idiopathic generalized epilepsy. Ann Neurol 2004;55:595-596.

4. Khosravani H, Altier C, Simms B, et al. Gating effects of mutations in the Cav3.2 T-type calcium channel associated with childhood absence epilepsy. J Biol Chem 2004;279:96819684 .

5. Khosravani H, Bladen C, Parker DB, et al. Effects of Cav3.2 channel mutations linked to idiopathic generalized epilepsy. Ann Neurol 2005;57:745-749.

6. Vitko I, Chen Y, Arias JM, et al. Functional characterization and neuronal modeling of the effects of childhood absence epilepsy variants of CACNA1H, a T-type calcium channel. J Neurosci 2005;25:4844-4855.

7. Heron SE, Khosravani H, Varela D, et al. Extended spectrum of idiopathic generalized epilepsies associated with CACNA1H functional variants. Ann Neurol 2007;62:560-568.

DOI: 10.1002 /ana.21275

\section{Alcohol and Stroke Risk: An Elusive Dose-Response Relationship}

Questions and controversies persist regarding the relationship of alcohol consumption with stroke. Although numerous studies have evaluated the relationship between alcohol intake and stroke risk, there are still gaps in our knowledge. The dose-response relationship between alcohol and stroke risk has been difficult to elucidate because of the heterogeneity of stroke subtypes, the potential differential effects across sex and race/ethnic groups, and the different beverage types and amounts of alcohol consumed.

In this issue of Annals of Neurology, the results of a large, prospective study among 68,036 Chinese men aged 40 years or older from the 1991 China National Hypertension Survey add to the data on the association of alcohol and stroke risk among Chinese people. ${ }^{1}$ The economic transformation of China has led to an increased production and consumption of alcohol, and a potentially enhanced public health threat. The association of alcohol and stroke risk has not been documented as thoroughly among Asian populations where the risk for hemorrhagic stroke is greater. Moreover, the protective effects of moderate alcohol consumption have not been substantiated among Asian cohorts. The majority of prior studies have been among white populations, and only one other cohort study on alcohol and stroke has been conducted among the Chinese population. ${ }^{2}$
The data from this large study support the association between heavy alcohol and stroke risk. There was a linear association between increasing alcohol consumption and all stroke incidence. The increased risk for stroke occurred among those drinking more that 21 drinks/week, whereas those drinking 1 to 6 drinks/ week had the lowest stroke risks. The relative risks were greater for the hemorrhagic stroke subgroup compared with the ischemic subgroup. For stroke mortality, a significant linear and marginally significant J-shaped or quadratic relationship was observed. The strengths of the study are the large sample size, the well-documented characterization of the exposures and outcomes, and the evaluation of this subject in a Chinese population.

Whether the relationship between alcohol and stroke differs by stroke subtype has been questioned. In prior studies, differential effects have been found between alcohol and ischemic or hemorrhagic stroke risk. ${ }^{3}$ No protective effects have been demonstrated between alcohol intake and hemorrhagic stroke, whereas a protective relationship has been documented for ischemic stroke. ${ }^{4}$ The results from this Chinese cohort support the differential relationship between alcohol consumption and stroke subtype. The deleterious effects of increasing alcohol were more notable for those classified as hemorrhagic strokes despite the smaller number of confirmed hemorrhagic strokes. Nearly 21\% (736/ 3,553 cases) of the strokes were not clearly classified as hemorrhagic or ischemic, which may lead to some difficulty interpreting the combined stroke subgroup. Moreover, the different directions of the association for the hemorrhagic and ischemic subgroups may warrant caution in the interpretation of the combined analysis.

For ischemic stroke, a J-shaped or quadratic relationship has been suggested by some studies with an increased stroke risk with larger amounts of alcohol and a reduced stroke risk with mild-to-moderate alcohol intake compared with a reference group of nondrinkers. ${ }^{4,5}$ For the confirmed ischemic cases in this Chinese cohort, no clear protective or J-shaped relationship between moderate alcohol consumption was found; however, a weak inverse linear trend was noted with all of the relative risks including the null value. A possible J-shaped curve was noted for stroke mortality. Among Chinese, therefore, moderate alcohol consumption appears to be not as protective for ischemic stroke, and excessive alcohol consumption is definitely deleterious for hemorrhagic stroke.

The elusive dose of alcohol that increases stroke risk or may be protective continues to be debated and has varied depending on the study. Some argue that for men anything more than two drinks/day would possibly increase stroke risks and five or more drinks/day definitely would. In a meta-analysis of 35 observational studies, those who drank 5 or more drinks/day had a 